FINANCIAL: Jurnal Akuntansi

Published by Program Studi Akuntansi STIE Sultan Agung Volume 7-Nomor 2, Desember 2021, (HIm 163-183)

ISSN-P: 2502-4574, ISSN-E: 2686-2581

Available online at: https://financial.ac.id/index.php/financiaI

\title{
ANALISIS PENGARUH TATA KELOLA PERUSAHAAN TERHADAP KESULITAN KEUANGAN PADA PERUSAHAAN YANG TERDAFTAR DI BURSA EFEK INDONESIA PERIODE 2016-2020
}

\author{
Robby Krisyadi ${ }^{1 *}$, Kelly ${ }^{2)}$ \\ ${ }^{1,2}$ Program Studi Akuntansi, Universitas Internasional Batam, Sei Ladi, Jl. Gajah Mada, Baloi Permai, \\ Kec. Sekupang, Kota Batam, Kepulauan Riau 29442, Indonesia \\ E-mail: 'robby.krisyadi@uib.ac.id, ${ }^{2} 1842090 . k e l l y @$ uib.edu
}

\begin{abstract}
Abstrak
Kesulitan keuangan merupakan kondisi penurunan keuangan suatu perusahaan. Perusahaan yang mengalami kesulitan keuangan akan mengancam kelangsungan hidup perusahaan. Salah satu faktor yang mempengaruhinya adalah tata kelola perusahaan yang buruk. Penelitian ini bertujuan untuk mengetahui pengaruh dari outside directors, managerial ownership, institutional ownership, independent commissioners, ukuran dewan komisaris, dan ukuran dewan direksi terhadap kesulitan keuangan. Populasi dari penelitian ini berupa seluruh perusahaan di Bursa Efek Indonesia dan sampelnya berupa laporan tahunan dari setiap populasi mulai dari periode 2016-2020 sebanyak 393 perusahaan. Teknik yang digunakan dalam penelitian ini berupa teknik purposive sampling dengan menggunakan metode regresi logistik. Hasil penelitian menyimpulkan bahwa institutional ownership dan ukuran dewan direksi memiliki pengaruh signifikan negatif pada kesulitan keuangan yang artinya semakin tinggi institutional ownership maka perusahaan akan semakin efisien dalam memanfaatkan asetnya sehingga kemungkinan terjadinya kesulitan keuangan dapat diminimalisir dan ukuran dewan direksi yang semakin tinggi akan mengurangi terjadinya agency problem yang dapat menimbulkan indikator kebangkrutan. Sedangkan, managerial ownership memiliki pengaruh signifikan positif terhadap kesulitan keuangan dikarenakan semakin tinggi saham yang dimiliki oleh manajerial maka manajemen mampu bertindak abuse power yang dapat mengakibatkan perusahaan mengalami kesulitan keuangan. Sementara itu, outside directors, independent commissioners, dan ukuran dewan komisaris tidak memiliki pengaruh terhadap kesulitan keuangan.
\end{abstract}

Kata Kunci: Likuiditas, Tata Kelola Perusahaan, Altman Z-Score, Firm Size, Leverage

\section{ANALYZING CORPORATE GOVERNANCE IMPACTED ON FINANCIAL DISTRESS IN COMPANIES LISTED ON THE INDONESIA STOCK EXCHANGE FOR THE PERIOD OF 2016-2020}

\begin{abstract}
Financial distress is a condition of a company's financial decline that can pose a risk of bankruptcy. Companies experiencing financial distress will threaten the survival of the company. One of the influencing factors is poor corporate governance. This study aims to determine the effect of outside directors, managerial ownership, institutional ownership, independent commissioners, board of commissioner size, and board of director size on financial distress. The population of this study is all companies on the Indonesia Stock Exchange and the sample is the annual reports from each population starting from the 2016-2020 period as many as 393 companies. The technique used in this research is purposive sampling technique using logistic regression method. The results of the study concluded that institutional ownership and board of director size have a significant negative effect on financial distress, which means that the higher of institutional ownership, the company will more efficient in utilizing its assets, so that the possibility of financial distress can be minimized and the higher of board of director size will reduce the occurrence of agency problems. which can lead to bankruptcy indicators. Meanwhile, managerial ownership has a positive significant effect on financial distress because the higher of shares owned by the managerial, the management is able to act abuse power which can cause the company to experience financial distress. Meanwhile, outside directors, independent commissioners, and board of commissioner size have no effect on financial distress.
\end{abstract}

Keywords: Liquidity, Corporate Governance, Altman Z-Score, Firm Size, Leverage

Article History: Received: 20 Sep 2021 Revised: 20 Okt 2021 Accepted: 04 Nop 2021 


\section{PENDAHULUAN}

Perkembangan dunia usaha pada saat ini sudah semakin menurun yang disebabkan oleh krisis ekonomi yang mengancam dunia usaha terutama bagi para pengusaha besar. Kondisi ekonomi global bagi perusahaan yang kuat merupakan peluang dan bagi perusahaan yang lemah merupakan sebuah ancaman. Salah satu kelemahan perusahaan adalah kesulitan keuangan.

Dalam menjalankan suatu bisnis tentu memiliki resiko. Resiko yang paling ditakuti adalah kegagalan bisnis terutama bagi suatu perusahaan. Kegagalan akan terjadi ketika laba menurun dan dana tidak mencukupi untuk membayar utang. Kondisi seperti itu disebut dengan kesulitan keuangan. Perusahaan yang mengalami kesulitan keuangan akan mengancam kelangsungan hidup perusahaan (Sumani, 2019).

Kesulitan keuangan adalah kondisi penurunan keuangan dalam suatu perusahaan dan jika tidak diantisipasi dengan baik akan mengalami kebangkrutan (Mesak \& Made, 2019). Fenomena ini tercermin ketika perusahaan mengalami kekurangan pada modal kerja untuk mengelola asetnya sehingga perusahaan membutuhkan tata kelola perusahaan yang baik (Sumani, 2019). Hal lain yang dapat menyebabkan terjadinya kesulitan keuangan ialah ketika fixed cost perusahaan mengalami peningkatan yang drastis, aset tidak dapat dicairkan, pendapatan menurun drastis sehingga berpengaruh terhadap resesi ekonomi (Khaliq et al., 2014). Karyawan yang bekerja di perusahaan yang sedang mengalami kesulitan keuangan akan membawakan dampak seperti tekanan karena kepercayaan dirinya menjadi lebih rendah dan juga takut akan kehilangan pekerjaan sehingga pekerja menjadi kurang produktif (Khaliq et al., 2014). Dalam menghadapi kondisi seperti itu, umumnya perusahaan akan meningkatkan biaya pinjaman tambahan modal dengan tujuan untuk meningkatkan dana yang diinginkan, dan manajemen dapat menjalankan proyek jangka panjang untuk memenuhi kewajiban jangka pendeknya (Khaliq et al., 2014).

Hal tersebut dapat dikaitkan pada kasus yang terjadi pada perusahaan yang tercatat di Bursa Efek Indonesia dimana terjadi penurunan pendapatan akibat dampak virus corona (Covid-19) sehingga menyebabkan cashflow tidak stabil karena emiten membutuhkan pengeluaran biaya operasi yang sama pada saat yang normal namun pendapatan terus menurun serta terjadinya pemutusan hubungan kerja pada karyawan (Sidik, 2020). Kondisi tersebut telah berlangsung hingga bulan Juni 2020 dan Asosiasi Emiten Indonesia menyebutkan terdapat lebih dari 50 perusahaan yang tercatat di Bursa Efek Indonesia mengalami kesulitan cashflow yang disebabkan oleh kasus pandemik (Sidik, 2020). Maka dari itu, manajemen memiliki peranan penting dalam mengambil ahli dan membuat keputusan dalam menangani kondisi keuangan perusahaan supaya tidak terjadi kebangkrutan.

Keberhasilan atau kegagalan suatu perusahaan sangat bergantung pada tata kelola perusahaannya (Pramudena, 2017). Maka dari itu, mekanisme tata kelola perusahaan yang baik harus diterapkan untuk menjaga kondisi keuangan yang baik. Apabila tata kelola perusahaan tidak direncanakan dengan baik akan mengakibatkan perusahaan mengalami kesulitan keuangan dimana kondisi keuangan perusahaan akan semakin memburuk dan dapat menyebabkan perusahaan mengalami kebangkrutan. Apabila suatu perusahaan memiliki tata kelola yang baik maka dapat mempertahankan dan membawa dampak 
positif terhadap kondisi keuangan perusahaan serta dapat meningkatkan kinerja perusahaan menjadi lebih maksimal. Penerapan tata kelola perusahaan dapat meminimalisir timbulnya masalah keagenan antara prinsipal dan agen sehingga dapat mengurangi resiko timbulnya kebangkrutan dalam perusahaan (Hanifah \& Purwanto, 2013).

Tata kelola perusahaan merupakan serangkaian aturan yang berfungsi untuk mengatur korelasi para pihak mengenai hak dan kewajiban dan memperhatikan kepentingannya guna untuk mencapai kepentingan dalam pemegang saham jangka panjang (Anggraini, 2014). Peran tata kelola perusahaan menjadi sangat penting dalam memberdayakan perusahaan agar lebih kompetitif. Penerapan tata kelola perusahaan akan membantu perusahaan dalam mengakses pasar modal internasional. Selain itu, dalam penerapan tata kelola diharapkan dapat membantu dalam meningkatkan daya saing dan dapat mengakses perusahaan terhadap sumber pendanaan secara globalisasi. Realisasi dari hasil tata kelola perusahaan merupakan suatu peningkatan kinerja perusahaan, sehingga dapat terlihat jelas bahwa sistem tata kelola yang optimal di perusahaan tentunya akan terhindar dari resiko kebangkrutan (Handayani et al., 2019).

Namun, terdapat beberapa perusahaan yang terdaftar di Bursa Efek Indonesia tidak menerapkan komitmen tata kelola dengan baik sehingga menimbulkan kasus kesulitan keuangan yang menimbulkan efek bagi masing-masing perusahaan itu sendiri. Salah satunya dapat dilihat dari kasus PT. Bakrie Telecom Tbk dimana perusahaan ini disuspensikan kembali oleh Bursa Efek Indonesia dengan alasan perusahaan tersebut mendapatkan "Opini Tidak Memberikan Pendapat (disclaimer of opinion)" dari seorang auditor selama 2 tahun berturut-turut (Ayuningtyas, 2019). Selanjutnya, diragukan adanya kecurangan terhadap nilai yang terdapat pada laporan keuangan dan auditor merasa tidak yakin dengan kegiatan bisnis perusahaan. Lalu, dilihat dari laporan keuangan perusahaan, ternyata nilai aset perusahaan tersebut mengalami penurunan yang drastis pada tahun 2010. Pada akhir kuartal ke-3 tahun lalu, total aset pada PT. Bakrie Telecom Tbk hanya tercatat sebesar Rp 738,95 miliar dari sebelumnya sebesar Rp 12,35 triliun pada akhir tahun 2010. Selanjutnya, total utang perusahaan mengalami peningkatan dari nilai sebesar $\mathrm{Rp}$ 7,16 triliun pada tahun 2010 menjadi Rp 15,82 triliun di akhir September 2018. Menurut kondisi tersebut, nilai ekuitas perusahaan otomatis akan tercatat negatif selama 6 tahun berturut-turut sejak pada tahun 2013. Berdasarkan kondisi laba dan neraca saldo perusahaan, maka dapat disimpulkan bahwa PT. Bakrie Telecom Tbk telah memasuki kategori kesulitan keuangan (Ayuningtyas, 2019).

Kasus lainnya dapat juga dilihat dari PT. Nusa Konstruksi Enjiniring Tbk dimana emiten tidak melaksanakan tata kelola perusahaan dengan baik sehingga perusahaan terlibat dalam kasus korupsi proyek pembangunan rumah sakit Universitas Udayana di Bali dan komisi pemberantasan korupsi juga menerapkan status tersangka terhadap PT. Nusa Konstruksi Enjiniring Tbk. Sehingga, Bursa Efek Indonesia melakukan suspensi sementara terhadap perdagangan saham pada perusahaan tersebut (Suprayitno, 2017).

Korelasi antara tata kelola perusahaan dengan kinerja keuangan akan saling mempengaruhi karena keberhasilan atau kegagalan suatu perusahaan sangat bergantung pada tata kelola perusahaan itu 
sendiri (Pramudena, 2017). Jika suatu perusahaan dapat mengontrol dengan baik secara tidak langsung kinerja perusahaan akan meningkat, serta kinerja keuangan di perusahaan dapat terkontrol dengan baik dan perusahaan akan sulit mengalami kerugian. Dengan demikian, dapat lebih mudah dalam menarik para investor untuk menanam saham di perusahaan tersebut.

Kajian studi terkait kesulitan keuangan telah banyak diuji dan dikaji oleh para peneliti sebelumnya dengan menggunakan berbagai variabel pengukuran diantaranya, penelitian Murhadi et al. (2018) menyatakan dalam risetnya bahwa outside directors memiliki pengaruh positif terhadap kesulitan keuangan. Sedangkan, riset yang diteliti oleh Ombaba \& Kosgei (2017) menjelaskan bahwa variabel outside directors memiliki signifikan negatif terhadap kesulitan keuangan. Penelitian oleh Yudha (2014), menemukan adanya signifikan negatif antara managerial ownership dan kesulitan keuangan. Hal ini tidak searah dengan penelitian yang dikemukakan oleh Khafid et al. (2019) dan Hanani \& Dharmastuti (2015) yang menemukan bahwa tidak terdapat adanya pengaruh antara managerial ownership dan kesulitan keuangan.

Riset Nurhujaima et al. (2021), menyatakan bahwa institutional ownership berpengaruh signifikan negatif terhadap kesulitan keuangan. Sementara, riset yang diteliti oleh Putri \& Merkusiwati (2014) menjelaskan bahwa institutional ownership secara signifikan tidak berpengaruh terhadap kesulitan keuangan. Hanifah \& Purwanto (2013) menyatakan dalam risetnya bahwa independent commissioners berpengaruh signifikan positif terhadap kesulitan keuangan. Sedangkan, riset Yanti et al. (2018) menjelaskan bahwa independent

Copyright (C) 2021, FINANCIAL: Jurnal Akuntansi commissioners tidak memiliki pengaruh terhadap kesulitan keuangan.

Penelitian Hanani \& Dharmastuti (2015), menemukan bahwa ukuran dewan komisaris memiliki pengaruh signifikan positif terhadap kesulitan keuangan. Namun, penelitian oleh Ibrahim (2019) menjelaskan terdapatnya hubungan signifikan negatif antara ukuran dewan komisaris dan kesulitan keuangan. Pramudena (2017) menjelaskan dalam risetnya bahwa terdapat hubungan signifikan positif antara ukuran dewan direksi dan kesulitan keuangan. Sedangkan, riset Harahap (2017) menemukan adanya signifikan negatif antara ukuran dewan direksi dan kesulitan keuangan.

Terdapat penelusuran dan penelitian yang dilakukan oleh beberapa peneliti terdahulu yang telah disebutkan di atas, maka penulis termotivasi untuk penelusuran lebih lanjut terkait pengaruh antara tata kelola perusahaan dan kesulitan keuangan. Indikator tata kelola perusahaan yang digunakan dalam penelitian ini ada 6 yaitu outside directors, managerial ownership, institutional ownership, independent commissioners, ukuran dewan komisaris, dan ukuran dewan direksi sebagai variabel independen. Selain itu, penulis juga menggunakan audit committee composition, external blockholder, likuiditas, leverage, dan firm size sebagai variabel kontrol dalam penelitian ini dengan tujuan untuk mengetahui ada tidaknya pengaruh dari faktor tata kelola perusahaan yang lain dan financial terhadap kesulitan keuangan.

\section{LANDASAN TEORI \\ Teori Agensi}

Jensen \& Meckling (1976) melakukan penelitian terhadap teori agensi dan menjelaskan bahwa teori agensi berupa sebuah teori yang menyatakan terdapatnya 
hubungan antara agen dan prinsipal. Landasan dari teori keagenan ialah asumsi bahwa kepentingan dari agen dan prinsipal itu berbeda, khususnya terdapat pemisahan antara kepemilikan dan pengendalian dalam perusahaan (Baklouti et al., 2016). Menurut teori agensi yang dikemukakan oleh Jensen \& Meckling (1976), menjelaskan bahwa terdapatnya pemisahan kepentingan antara pemilik dan pengelola perusahaan dapat menimbulkan konflik. Salah satu penyebab terjadinya masalah keagenan karena adanya information asymmetry. Information asymmetry menimbulkan dua masalah yang disebabkan oleh prinsipal yang mengalami kesulitan dalam memantau dan mengontrol tindakan agen (Fashhan \& Fitriana, 2018).

\section{Stewardship Theory}

Stewardship theory dibangun atas filosofi dari sifat manusia, bahwa manusia itu mampu bertindak dengan penuh tanggung jawab, memiliki integritas, dapat di percaya dan dapat bersikap jujur terhadap orang lain (Sumani, 2019). Dalam perspektif stewardship memandang direktur dan manajer sebagai agen perusahaan sehingga direktur cenderung memaksimalkan kekayaan pemegang saham (Ombaba \& Kosgei, 2017). Dalam stewardship theory, manajer termotivasi dalam menjalankan tugasnya serta kewajiban dalam mencapai tujuan organisasi sehingga struktur tata kelola dalam perusahaan akan tertata secara maksimal.

\section{Tata Kelola Perusahaan}

Tata kelola perusahaan merupakan mekanisme yang berfungsi untuk melindungi hak-hak pemangku kepentingan yang berbeda. Hal ini digunakan dalam menentukan hak distribusi dan tanggung jawab sebagai pemegang saham, dewan Copyright (C) 2021, FINANCIAL: Jurnal Akuntansi direksi, serta manajer (John \& Ogechukwu, 2018). Mekanisme tata kelola perusahaan memiliki tujuan dalam menciptakan nilai tambah bagi semua pihak yang berkepentingan supaya tidak terjadi perselisihan antara agen dan prinsipal yang berdampak pada kelancaran kinerja perusahaan dan dapat menghindari kemungkinan terjadinya financial distress (Fashhan \& Fitriana, 2018).

Tata kelola perusahaan bertujuan untuk memberikan kepastian bahwa manajer dalam perusahaan dapat bertindak secara tepat, tidak egois, dan melindungi seluruh pemangku kepentingan di dalam perusahaan (Murtadha et al., 2018). Tata kelola perusahaan memiliki tujuan dalam menciptakan suatu nilai tambahan kepada seluruh pemangku kepentingan (Ibrahim, 2019). Oleh karena itu, penting untuk mengeksplorasi dampak yang ditimbulkan dalam menerapkan tata kelola perusahaan terhadap kesulitan keuangan (Jamal \& Shah, 2017).

\section{Kesulitan Keuangan}

Kesulitan keuangan merupakan suatu kondisi ketika perusahaan sedang mengalami beban dalam menjalankan tanggung jawabnya dan total biaya lebih besar dari total pendapatan sehingga perusahaan menjadi rugi (Handayani et al., 2019). Kesulitan keuangan merupakan situasi perusahaan ketika tidak sanggup melunasi utang kepada kreditur yang disebabkan oleh jangka panjang dan pendek (Islami \& Rio, 2018).

Apabila kesulitan keuangan tidak dapat terkendali maka perusahaan akan mengalami kendala lebih lanjut baik financial maupun non-financial (Pramudena, 2017). Fenomena ini tercermin ketika modal kerja perusahaan menurun sehingga tidak mampu dalam 
mengelola asetnya dan perusahaan tidak sanggup melunasi kewajiban yang segera jatuh tempo, maka kesulitan keuangan perlu dideteksi sejak dini supaya perusahaan dapat melaksanakan tindakan sebelum perusahaan tersebut mengalami kebangkrutan (Sumani, 2019).

\section{Pengaruh Variabel Independen Terhadap Variabel Dependen}

Pengaruh Outside Directors Terhadap Kesulitan Keuangan

Outside directors adalah direktur independen atau non-eksekutif yang berperan dalam menentukan profitabilitas perusahaan melemah pada saat periode krisis (Kyriazopoulos, 2017). Menurut riset Manzaneque et al. (2016), menyatakan bahwa variabel outside directors memiliki hubungan dengan arah yang negatif terhadap kesulitan keuangan karena perusahaan dengan proporsi outside directors yang lebih besar cenderung dapat meminimalisir timbulnya kesulitan keuangan terhadap perusahaan. Hal ini sepadan dengan riset yang ditemukan oleh Udin et al. (2020) dan Ombaba \& Kosgei (2017) yang menjelaskan dalam risetnya bahwa outside directors memiliki pengaruh negatif terhadap kesulitan keuangan.

H1: Outside directors berpengaruh negatif terhadap kesulitan keuangan

\section{Pengaruh Managerial Ownership Terhadap Kesulitan Keuangan}

Managerial ownership mengartikan sebagai suatu kondisi yang menunjukkan bahwa manajer mempunyai kepentingan sekaligus pemegang saham dalam perusahaan. Hal tersebut dapat diketahui dalam persentase kepemilikan manajemen perusahaan yang biasanya dimiliki oleh para dewan komisaris dan direksi (Anggraini, Copyright (C) 2021, FINANCIAL: Jurnal Akuntansi
2014). Penelitian Widhiadnyana \& Ratnadi (2019) menjelaskan terdapatnya pengaruh negatif antara managerial ownership dan kesulitan keuangan. Semakin besar persentase saham yang dimiliki oleh para dewan direksi dan komisaris pada suatu perusahaan maka persentase kemungkinan terjadinya kesulitan keuangan pada perusahaan akan semakin kecil karena adanya managerial ownership menyebabkan manajer akan lebih waspada dalam menentukan dan mengambil keputusan (Widhiadnyana \& Ratnadi, 2019). Riset tersebut didukung oleh Pramudena (2017) dan Yudha (2014) yang memperoleh hasil signifikan negatif antara managerial ownership dan kesulitan keuangan.

$\mathrm{H} 2$ : Managerial ownership berpengaruh negatif terhadap kesulitan keuangan

\section{Pengaruh Institutional Ownership Terhadap Kesulitan Keuangan}

Institutional ownership berfungsi untuk meminimalisir terjadinya masalah keagenan karena pada dasarnya pemegang saham institutional bertugas untuk membantu perusahaan dalam mengawasi manajemen supaya tidak menimbulkan hal yang merugikan pemegang saham. Setyaningsih \& Gunarsih (2018) menjelaskan terdapatnya pengaruh negatif antara institutional ownership dan kesulitan keuangan karena semakin besar institutional ownership maka perusahaan akan semakin efisien dalam memanfaatkan asetnya sehingga kemungkinan terjadinya kesulitan keuangan dapat diminimalisir. Hal tersebut terjadi karena kepemilikan investor institusi akan semakin ketat dalam melakukan pengawasan terhadap manajemen ketika menyajikan laporan keuangan, sehingga manajemen aktif dalam menjalankan kinerja dan melaporkan nilai laba bersih dalam 
laporan keuangan (Setyaningsih \& Gunarsih, 2018). Kajian tersebut searah dengan riset yang dikemukakan oleh Nurhujaima et al. (2021) dan Maghfiroh \& Isbanah (2020) yang memperoleh hasil signifikan negatif antara institutional ownership dan kesulitan keuangan.

H3: Institutional ownership berpengaruh negatif terhadap kesulitan keuangan

\section{Pengaruh Independent Commissioners Terhadap Kesulitan Keuangan}

Independent commissioners adalah bagian dari dewan komisaris yang bertugas untuk bertindak sebagai pengawas manajer dalam penerapan sistem tata kelola perusahaan. Independent commissioners dalam struktur dewan komisaris dianggap memiliki kinerja dalam meningkatkan efektivitas dewan komisaris (Widhiadnyana \& Ratnadi, 2019). Hanifah \& Purwanto (2013) menjelaskan dalam risetnya bahwa independent commissioners memiliki hubungan signifikan positif terhadap kesulitan keuangan. Seberapa besar proporsi independent commissioners tidak mampu dalam menghindari terjadinya kesulitan keuangan (Hanifah \& Purwanto, 2013). Hasil riset tersebut sejalan dengan riset yang dikemukakan oleh Widhiadnyana \& Ratnadi (2019).

$\mathrm{H} 4$ : Independent commissioners berpengaruh positif terhadap kesulitan keuangan

\section{Pengaruh Ukuran Dewan Komisaris Terhadap Kesulitan Keuangan}

Dewan komisaris merupakan bagian dari dewan dalam suatu tata kelola perusahaan yang berfungsi sebagai pengawas, upaya meminimalisir agency problem agar timbul keselarasan kepentingan antara pemilik dan pihak manajer (Hanifah \& Purwanto, 2013). Berdasarkan studi oleh Copyright (C) 2021, FINANCIAL: Jurnal Akuntansi
Hanifah \& Purwanto (2013) menjelaskan seberapa banyak dewan komisaris perusahaan tetap sulit untuk menghindari dari kesulitan keuangan. Riset yang dihasilkan oleh Hanifah \& Purwanto menjelaskan bahwa ukuran dewan komisaris memiliki hubungan signifikan positif terhadap kesulitan keuangan. Hasil tersebut searah dengan riset yang dikemukakan oleh Hanani \& Dharmastuti (2015) yang memperoleh hasil signifikan dengan arah positif.

H5: Ukuran dewan komisaris berpengaruh positif terhadap kesulitan keuangan

\section{Pengaruh Ukuran Dewan Direksi Terhadap Kesulitan Keuangan}

Dalam teori agency menjelaskan dewan direksi sebagai suatu mekanisme dalam tata kelola perusahaan yang berfungsi untuk mengurangi masalah agency dalam jangka panjang upaya menghindari terjadinya indikator kebangkrutan atau menciptakan nilai tambah demi kepentingan semua pihak agar tidak terjadinya perselisihan antara pihak agen dan prinsipal (Hanifah \& Purwanto, 2013). Berdasarkan penelitian oleh Sumani (2019) membuktikan bahwa ukuran dewan direksi berpengaruh signifikan negatif terhadap kesulitan keuangan karena semakin tinggi jumlah dewan direksi menandakan kemungkinan terjadinya financial distress pada perusahaan akan semakin kecil pula. Hasil riset tersebut sepadan dengan riset Khurshid et al. (2019) yang menjelaskan bahwa ukuran dewan direksi memiliki pengaruh negatif terhadap kesulitan keuangan.

H6: Ukuran dewan direksi berpengaruh negatif terhadap kesulitan keuangan 
Pengaruh Variabel Kontrol Terhadap Variabel Dependen

Pengaruh Audit Committee Composition Terhadap Kesulitan Keuangan

Audit committee ialah kumpulan komite yang dibentuk oleh keputusan dewan komisaris untuk menjalankan tugas dan fungsinya serta memiliki tanggung jawab kepada dewan direksi (Sumani, 2019). Audit committee merupakan bagian dari mekanisme tata kelola perusahaan yang diasumsikan mampu mengurangi agency problem (Hanifah \& Purwanto, 2013). Audit committee memiliki peran penting dalam perusahaan dimana peran tersebut telah dikategorikan ke dalam beberapa karakteristik atau komponen, diantaranya kompetensi komite audit, independensi komite audit, ukuran komite audit, dan frekuensi pertemuan komite audit (Revitasari et al., 2017). Audit committee yang diaplikasikan dalam penelitian ini berupa independensi komite audit dimana perusahaan memiliki komite audit yang dijabat oleh komisaris independen atau yang berasal dari luar, tidak memiliki hubungan, dan tidak memiliki saham di perusahaan tersebut karena tujuan dari independensi ialah untuk menjaga kredibilitas serta penilaian yang objektif terhadap suatu laporan. Penelitian terdahulu memperoleh hasil bahwa audit committee composition memiliki pengaruh negatif terhadap kesulitan keuangan (Khalid et al., 2020).

\section{Pengaruh External Blockholder Terhadap Kesulitan Keuangan}

External blockholder ialah pemegang saham individual dengan jumlah persentase kumulatif dari seluruh total saham yang dimiliki oleh pemegang saham lebih dari $20 \%$ dan tidak berafiliasi dengan manajemen (Elloumi \& Gueyié, 2001). Perusahaan yang Copyright (C) 2021, FINANCIAL: Jurnal Akuntansi mengalami kesulitan keuangan cenderung tidak memiliki pemegang saham external yang lebih dari 20\% (Elloumi \& Gueyié, 2001). Block yang biasa dimiliki oleh perwalian keluarga, rencana kepemilikkan saham karyawan perusahaan, dan rencana pensiun dikecualikan karena manajemen puncak umumnya mengontrol hak suara mereka (Elloumi \& Gueyié, 2001). Blockholder dalam perusahaan berfungsi sebagai rekomendasian kepada direksi yang kinerjanya kurang maksimal atau di bawah standar, sehingga dapat membuat manajer cepat dalam bertindak (Miglani et al., 2015). Penelitian terdahulu memperoleh hasil bahwa blockholder ownership secara signifikan tidak memiliki pengaruh terhadap kesulitan keuangan (Widyasari \& Kurniawan, 2020); (Maghfiroh \& Isbanah, 2020).

\section{Pengaruh Likuiditas Terhadap Kesulitan Keuangan}

Semakin tinggi nilai current ratio menunjukkan adanya kelebihan aset lancar atau kas pada perusahaan yang artinya perusahaan tidak dapat mengelola dengan benar sehingga menyebabkan profitabilitas berkurang dan sebaliknya jika nilai current ratio semakin rendah menunjukkan bahwa perusahaan memiliki modal yang lebih sedikit untuk membayar utang jangka pendeknya, artinya perusahaan sedang mengalami kondisi keuangan yang kurang sehat dan sebaliknya. Hal ini akan memberikan sinyal buruk bagi para investor dalam bertindak untuk berinvestasi saham di perusahaan (Heniwati \& Essen, 2020). Hasil studi oleh Heniwati \& Essen (2020) mengungkapkan bahwa likuiditas tidak memiliki pengaruh terhadap kesulitan keuangan. Hal ini tidak searah dengan studi yang dikemukakan oleh Zelie (2019) dimana hasilnya membuktikan bahwa likuiditas 
berpengaruh signifikan positif terhadap kesulitan keuangan.

\section{Pengaruh Leverage Terhadap Kesulitan Keuangan}

Semakin besar laba yang dihasilkan, maka nilai leverage akan semakin besar pula. Hal ini menunjukkan keefektifan suatu perusahaan ketika mengelola asetnya sehingga perusahaan dapat memperoleh keuntungan maka perusahaan akan sulit mengalami kesulitan keuangan karena memiliki nilai rasio leverage yang tinggi (Hanifah \& Purwanto, 2013). Leverage juga berfungsi untuk mengukur tingkat kejauhan suatu aset perusahaan yang dibiayai oleh utang. Apabila dalam proses pembiayaan, perusahaan cenderung lebih banyak menggunakan utang, maka perusahaan akan sulit melakukan pembayaran di masa yang akan datang karena nilai utang lebih tinggi daripada aset yang dimilikinya (Hanifah \& Purwanto, 2013). Berdasarkan hasil riset oleh Hanifah \& Purwanto (2013), menunjukkan terdapatnya pengaruh positif antara leverage dan kesulitan keuangan. Namun, hasil penelitian tersebut tidak searah dengan riset yang dikemukakan oleh Zelie (2019) yang menjelaskan adanya pengaruh signifikan negatif antara leverage dan kesulitan keuangan.

\section{Pengaruh Firm Size Terhadap Kesulitan Keuangan}

Firm size adalah sebuah gambaran mengenai besarnya aset yang dimiliki perusahaan (Rianti \& Yadiati, 2018). Semakin besar ukuran suatu perusahaan berdasarkan nilai aset menunjukkan bahwa perusahaan memiliki modal yang cukup untuk menjalankan kegiatan operasionalnya sehingga perusahaan dapat melakukan inovasi produk baru untuk menarik pasar Copyright (C) 2021, FINANCIAL: Jurnal Akuntansi atau melakukan ekspansi bisnis (Heniwati \& Essen, 2020). Penelitian Murtadha et al. (2018) menjelaskan dalam risetnya bahwa firm size berpengaruh negatif terhadap kesulitan keuangan. Hal tersebut sependapat dengan riset yang dikemukakan oleh Putri \& Merkusiwati (2014).

\section{METODE}

Riset yang dikaji dalam penelitian ini berupa penelitian kuantitatif. Jenis data yang digunakan dalam penelitian ini berupa time series karena data akan diambil selama 5 tahun berturut-turut mulai dari tahun 2016 hingga 2020. Populasi yang diambil berupa seluruh perusahaan yang ada di Bursa Efek Indonesia. Sampel penelitian berupa laporan keuangan dan laporan tahunan yang dimulai dari periode tahun 2016 hingga 2020. Kriteria penyeleksian sampel dengan metode purposive sampling diantaranya, perusahaan yang terdaftar di Bursa Efek Indonesia yang telah menerbitkan laporan tahunan paling sedikit 5 tahun mulai dari tahun 2016-2020, melaporkan informasi data pada laporan tahunan secara lengkap dan jelas sesuai data yang akan diambil terkait variabel penelitian, serta perusahaan yang masih dalam keadaan aktif seiring dengan berjalannya waktu penelitian. Berdasarkan kriteria sampel, perusahaan yang memenuhi kriteria berjumlah 722 perusahaan dengan jumlah data sampel sebanyak 1.965 data.

\section{Definisi Operasional \\ Variabel Dependen}

Kesulitan keuangan berupa variabel dependen dalam penelitian ini yang diukur dengan variabel dummy. Variabel dummy merupakan bagian dari jenis variabel yang berperan dalam mengkuantitatifkan variabel yang bersifat kualitatif yaitu dengan memberikan kode 0 pada entitas yang sehat 
dan kode 1 pada entitas yang mengalami kesulitan keuangan (Ibrahim, 2019). Berikut teknik dalam menentukan entitas yang sehat atau tidak dengan menggunakan rumus Altman Z-score yaitu sebagai berikut (Zelie, 2019):

$$
Z^{\prime \prime}=6.56 \times 1+3.26 \times 2+6.72 \times 3+1.05 \times 4
$$

Keterangan:

$$
\begin{aligned}
& \mathrm{X} 1: \frac{\text { Working Capital }}{\text { Total Asset }} \\
& \mathrm{X} 2: \frac{\text { Retained Earnings }}{\text { Total Asset }} \\
& \mathrm{X} 3: \frac{\text { EBIT }}{\text { Total Asset }} \\
& \mathrm{X} 4: \frac{\text { BookValue of Equity }}{\text { Total Debt }}
\end{aligned}
$$

\section{Variabel Independen}

\section{Outside Directors}

Variabel ini diukur dengan memakai proporsi atau perbandingan dari outside directors yaitu semua anggota dewan yg dianggap sebagai direktur luar semua masuk ke dalam proporsi outside directors. Berikut rumus yang dapat digunakan untuk menentukan outside directors adalah sebagai berikut (Elloumi \& Gueyié, 2001):

$$
O D=\frac{\text { Direktur Independen }}{\text { Total Dewan Direksi }}
$$

\section{Managerial Ownership}

Variabel ini diukur dengan melihat besarnya jumlah atau proporsi dari masingmasing saham yang diperoleh manajemen pada tahun berakhir dan disajikan dalam bentuk persentase. Berikut rumus managerial ownership sebagai berikut (Ibrahim, 2019):

$$
M O=\frac{\text { Jumlah Saham yang dimiliki Manajerial }}{\text { Jumlah Saham yang Beredar }}
$$

\section{Institutional Ownership}

Variabel ini diukur dengan melihat besarnya jumlah atau proporsi dari saham yang dimiliki oleh institusi pada akhir tahun dan disajikan dalam bentuk persentase. Berikut rumus institutional ownership sebagai berikut (Ibrahim, 2019):

$$
I O=\frac{\sum \text { Saham Institutional }}{\sum \text { Saham yang Beredar }}
$$

\section{Independent Commissioners}

Menurut peneliti Ibrahim (2019), variabel ini diukur dengan rumus sebagai berikut:

$$
I C=\frac{\sum \text { Independen Komisaris }}{\sum \text { Dewan Komisaris }}
$$

\section{Ukuran Dewan Komisaris}

Variabel ini diukur dengan melihat banyaknya jumlah komisaris dalam suatu perusahaan (Ibrahim, 2019).

\section{Ukuran Dewan Direksi}

Variabel ini diukur dengan melihat banyaknya jumlah direksi dalam suatu perusahaan (Ibrahim, 2019).

\section{Variabel Kontrol Audit Committee Composition}

Audit Committee Composition yang diaplikasi dalam penelitian ini berupa independensi komite audit yang berfungsi untuk menjaga kredibilitas serta penilaian yang objektif terhadap suatu laporan. Variabel ini diukur dengan variabel dummy. Jika diberi kode 0 apabila komite audit yang tidak secara keseluruhan berasal dari pihak luar dan kode 1 apabila komite audit yang secara keseluruhan berasal dari pihak luar, tidak ada hubungan keluarga, dan tidak pernah bekerja pada perusahaan tersebut (Elloumi \& Gueyié, 2001). 


\section{External Blockholder}

Variabel ini diukur dengan melihat persentase kumulatif saham biasa dengan kepemilikan saham yang lebih dari $20 \%$ dan tidak terafiliasi dengan manajemen. External blockholder diukur untuk mengetahui tingkat kepemilikkan saham external yang lebih dari $20 \%$ yang dimiliki oleh perusahaan. Berikut rumus yang diaplikasikan dalam penelitian ini sebagai berikut (Elloumi \& Gueyié, 2001):

$$
E B=\frac{\sum \text { Saham }>20 \%}{\sum \text { Saham yang Beredar }}
$$

\section{Likuiditas}

Likuiditas berupa rasio yang berfungsi untuk mengukur tingkat kemampuan sebuah perusahaan dalam melunasi kewajiban lancarnya secara tepat waktu dan aktivitas operasi perusahaan. Variabel ini diukur dengan rumus sebagai berikut (Elloumi \& Gueyié, 2001):

$$
\text { Likuiditas }=\frac{\sum \text { Aset Lancar }}{\sum \text { Kewajiban Lancar }}
$$

\section{Leverage}

Leverage berupa rasio yang berfungsi untuk mengukur tingkat kejauhan suatu aset perusahaan yang dibiayai oleh utang. Variabel ini diukur dengan rumus sebagai berikut (Ibrahim, 2019):

$$
\text { Leverage }=\frac{\sum \text { Utang }}{\sum \text { Aset }}
$$

\section{Firm Size}

$$
\text { Firm size diukur dengan }
$$

memperkirakan logaritma natural (Ln) dari total aset perusahaan. Firm size berfungsi untuk memberikan gambaran mengenai besaran aset yang dimiliki perusahaan.
Berikut rumus yang dapat menentukan firm size antara lain (Ibrahim, 2019):

$$
\text { Firm Size }=\text { Ln (Total Aset })
$$

\section{Teknik Pengumpulan Data}

Teknik pengumpulan data yang diaplikasikan dalam riset ini berupa data sekunder. Data yang dikumpulkan mulai dari tahun 2016 hingga 2020 dengan tujuan untuk mendukung kelancaran dalam penelitian ini. Data penelitian yang dikumpulkan berupa laporan keuangan dan laporan tahunan jika tersedia. Laporan tahunan tersebut bukan didapatkan langsung dari perusahaannya namun didapatkan melalui situs http://www.idx.co.id (Indonesia Stock Exchange) dan juga dapat ditemukan pada situs resmi perusahaan tersebut.

\section{Teknik Analisis Data}

Teknik analisis data yang diaplikasikan dalam riset ini berupa metode regresi logistik karena variabel dependen dalam riset ini berupa variabel dummy. Data yang berhasil dikumpulkan akan diuji dengan menggunakan software SPSS versi 25 . Berikut model regresi logistik yang digunakan dalam penelitian ini:

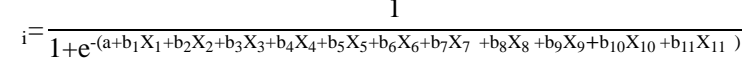

\section{Keterangan:}

$\Pi_{\mathrm{i}} \quad=$ Kesulitan Keuangan

$\mathrm{X}_{1} \quad=$ Outside Directors

$\mathrm{X}_{2} \quad=$ Managerial Ownership

$\mathrm{X}_{3} \quad=$ Institutional Ownership

$\mathrm{X}_{4} \quad=$ Independent Commissioners

$\mathrm{X}_{5}=$ Ukuran Dewan Komisaris

$\mathrm{X}_{6}=$ Ukuran Dewan Direksi

$\mathrm{X}_{7}=$ Audit Committee Composition

$\mathrm{X}_{8}=$ External Blockholder

$\mathrm{X}_{9} \quad=$ Likuiditas

$\mathrm{X}_{10}=$ Leverage

$\mathrm{X}_{11}=$ Firm Size

$e \quad=$ error 


\section{HASIL DAN PEMBAHASAN Uji Statistik Deskriptif}

Tabel 1. Hasil Uji Statistik Deskriptif Variabel Independen dan Kontrol

\begin{tabular}{|c|c|c|c|c|c|}
\hline $\begin{array}{c}\text { Variab } \\
\text { el }\end{array}$ & $\mathbf{N}$ & Min. & Maks. & $\begin{array}{c}\text { Rata- } \\
\text { rata }\end{array}$ & $\begin{array}{l}\text { Standar } \\
\text { Deviasi }\end{array}$ \\
\hline OD & 1.757 & 0,0000 & 0,5000 & 0,1428 & 0,1442 \\
\hline MO & 1.757 & 0,0000 & 0,4802 & 0,0318 & 0,0796 \\
\hline $\mathrm{IO}$ & 1.757 & 0,0000 & 0,9977 & 0,6457 & 0,2370 \\
\hline IC & 1.757 & 0,1667 & 0,7500 & 0,4076 & 0,1019 \\
\hline $\begin{array}{c}\text { Uk. } \\
\text { Dewan } \\
\text { Komis } \\
\text { aris }\end{array}$ & 1.757 & 2,0 & 9,0 & 4,13 & 1,656 \\
\hline $\begin{array}{c}\text { Uk. } \\
\text { Dewan } \\
\text { Direksi }\end{array}$ & 1.757 & 2,0 & 10,0 & 4,66 & 1,736 \\
\hline EB & 1.757 & 0,0000 & 0,9971 & 0,5725 & 0,2597 \\
\hline $\begin{array}{c}\text { Likuidi } \\
\text { tas }\end{array}$ & 1.757 & 0,0002 & $\begin{array}{c}46,997 \\
2\end{array}$ & 2,4080 & 3,5536 \\
\hline $\begin{array}{c}\text { Levera } \\
\text { ge }\end{array}$ & 1.757 & 0,0127 & $\begin{array}{c}36,695 \\
7\end{array}$ & 0,6377 & 1,6499 \\
\hline $\begin{array}{c}\text { Firm } \\
\text { Size }\end{array}$ & 1.757 & $\begin{array}{c}17.009 . \\
196.12 \\
4\end{array}$ & $\begin{array}{c}338.20 \\
3.000 .0 \\
00.000 \\
\end{array}$ & $\begin{array}{c}10.824 . \\
945.23 \\
6.861\end{array}$ & $\begin{array}{c}22.899 .3 \\
56.212 .7 \\
71\end{array}$ \\
\hline $\begin{array}{c}\text { Valid } \\
N\end{array}$ & 1.757 & & & & \\
\hline
\end{tabular}

Sumber: Data sekunder diolah (2021)

Data yang terdapat pada tabel di atas berjumlah 1.757 data setelah dihapusnya data outlier. Pada Tabel 1 dapat diketahui bahwa hasil rata-rata Outside Directors (OD) menunjukkan nilai sebesar $14,28 \%$ yang artinya jumlah rata-rata Outside Directors (OD) yang dimiliki oleh perusahaan sebesar $14,28 \%$ dengan jumlah minimum sebesar 0,0000 dan jumlah maksimum sebesar 0,5000 serta memiliki nilai standar deviasi sebesar 14,42\% yaitu lebih rendah dari $33 \%$ sehingga dinyatakan bahwa Outside Directors memiliki variasi yang rendah. Hasil rata-rata dari Managerial Ownership (MO) menunjukkan nilai sebesar 0,0318 yang artinya jumlah persentase saham yang dimiliki oleh para dewan komisaris dan direksi yang turut aktif dalam mengambil keputusan di perusahaan yang tercatat dalam Bursa Efek Indonesia memiliki jumlah ratarata sebesar $3.18 \%$ dengan jumlah maksimum sebesar 0,4802 oleh PT. Duta Anggada Realty Tbk pada tahun 2018. Managerial Ownership (MO) memiliki nilai standar deviasi sebesar 7,96\% lebih kecil dari $33 \%$ artinya variasi yang dimiliki Managerial Ownership (MO) merupakan variasi yang rendah.

Jumlah rata-rata dari variabel Institutional Ownership (IO) memiliki nilai sebesar 0,6457 yang artinya jumlah saham yang dimiliki oleh pihak luar berupa investor institusi dalam mengawasi kinerja manajemen yang terdapat pada perusahaan yang tercatat di Bursa Efek Indonesia memiliki tingkat rata-rata sebesar $64,57 \%$. Besarnya persentase saham institusi yang dimiliki oleh perusahaan di Bursa Efek Indonesia sebesar 99,77\%. Standar deviasi yang dimiliki oleh Institutional Ownership (IO) memiliki nilai sebesar $23,70 \%$ yaitu lebih rendah dari $33 \%$ sehingga variasi yang dimiliki Institutional Ownership (IO) merupakan variasi yang rendah. Nilai ratarata yang dimiliki oleh Independent Commissioners (IC) sebesar 0,4076 yang artinya jumlah rata-rata Independent Commissioners (IC) yang dimiliki oleh perusahaan yang ada di Bursa Efek Indonesia sebesar 40,76\% dengan jumlah minimun sebesar 0,1667 dan jumlah maksimum sebesar 0,7500. Independent Commissioners (IC) merupakan variasi yang rendah karena memiliki nilai standar deviasi sebesar $10,19 \%$ lebih rendah dari $33 \%$.

Nilai rata-rata yang dimiliki oleh ukuran dewan komisaris sebesar 4,13 mendefinisikan bahwa sampel perusahaan dalam penelitian ini memiliki jumlah ratarata dewan komisaris sebanyak 4 orang dengan jumlah maksimum sebanyak 9 orang dan jumlah minimum sebanyak 2 orang. Ukuran dewan komisaris memiliki variasi yang tinggi karena memiliki nilai standar 
deviasi sebesar $166 \%$ lebih tinggi dari $33 \%$. Nilai rata-rata yang dimiliki oleh ukuran dewan direksi sebesar 4,66 mendefinisikan bahwa rata-rata perusahaan di Bursa Efek Indonesia memiliki dewan direksi sebanyak 4 hingga 5 orang dengan jumlah maksimum sebanyak 10 orang dan jumlah minimum sebanyak 2 orang. Ukuran dewan direksi merupakan variasi yang tinggi karena memiliki nilai standar deviasi sebesar $174 \%$ lebih besar dari $33 \%$.

Nilai rata-rata dari External Blockholder (EB) sebesar 57,25\% yang artinya jumlah rata-rata saham yang dimiliki oleh perusahaan di Bursa Efek Indonesia sebesar $57,25 \%$ dengan jumlah minimum sebesar 0\% dan jumlah maksimum sebesar $99,71 \%$. Nilai rata-rata yang dimiliki oleh likuiditas diukur dengan perhitungan rasio yaitu total aset lancar pada total kewajiban lancar yakni 2,4080 yang artinya sebesar $241 \%$ utang lancar perusahaan di Bursa Efek Indonesia dibayar dengan aset lancar. Angka maksimum pada likuiditas sebesar 46,9972 yang terdapat pada tahun 2016 oleh PT. Akbar Indomakmur Stimec Tbk.

Nilai rata-rata dari leverage diukur dengan perhitungan rasio yaitu total utang pada total aset yakni 0,6377 yang artinya sebesar $63,77 \%$ aset perusahaan di Bursa Efek Indonesia dibayar dengan utang. Nilai maksimum pada leverage sebesar 36,6957 yang terdapat pada tahun 2020 oleh PT. Trikomsel Oke Tbk. Nilai rata-rata dari firm size sebesar Rp10.824.945.236.861 yang artinya rata-rata perusahaan yang terdapat di Bursa Efek Indonesia memiliki total aset sebesar Rp10.824.945.236.861. Nilai minimum dari firm size sebesar Rp17.009.196.124 yang dimiliki oleh PT. Akbar Indomakmur Stimec Tbk pada tahun 2016, sedangkan nilai maksimum dari firm size sebesar Rp338.203.000.000.000 yang Copyright (C) 2021, FINANCIAL: Jurnal Akuntansi dimiliki oleh PT. Astra International Tbk pada tahun 2020.

Tabel 2. Hasil Uji Statistik Deskriptif Variabel Dependen (Dummy)

\begin{tabular}{|c|c|c|c|}
\hline Variabel & Kategori & Frekuensi & Presentasi \\
\hline \multirow{3}{*}{$\begin{array}{c}\text { Kesulitan } \\
\text { Keuangan }\end{array}$} & $\begin{array}{c}\text { Tidak } \\
\text { Kesulitan } \\
\text { Keuangan }\end{array}$ & 1.334 & 75,9 \\
\cline { 2 - 4 } & $\begin{array}{c}\text { Kesulitan } \\
\text { Keuangan }\end{array}$ & 423 & 24,1 \\
\cline { 2 - 4 } & Total & 1,757 & 100 \\
\hline
\end{tabular}

Sumber: Data sekunder diolah (2021)

Pada Tabel 2 dapat diketahui hasil dari uji statistik deskriptif untuk variabel kesulitan keuangan memperoleh hasil sebanyak 1.334 data atau setara $75,9 \%$ perusahaan berupa kategori tidak kesulitan keuangan, sedangkan 423 data atau setara $24,1 \%$ perusahaan berupa kategori kesulitan keuangan.

Tabel 3. Hasil Uji Statistik Deskriptif Variabel Kontrol (Dummy)

\begin{tabular}{|c|c|c|c|}
\hline Variabel & Kategori & Frekuensi & Presentasi \\
\hline \multirow{4}{*}{ ACC } & $\begin{array}{c}\text { Tidak semua } \\
\text { komite audit } \\
\text { berasal dari } \\
\text { luar }\end{array}$ & 82 & 4,7 \\
\cline { 2 - 4 } & $\begin{array}{c}\text { Semua komite } \\
\text { audit berasal } \\
\text { dari luar }\end{array}$ & 1.675 & 95,3 \\
\cline { 2 - 4 } & Total & 1,757 & 100 \\
\hline
\end{tabular}

Sumber: Data sekunder diolah (2021)

Tabel 3 menunjukkan bahwa variabel Audit Committee Composition (ACC) memperoleh hasil sebanyak 82 data atau setara $4,7 \%$ komite audit yang secara keseluruhan tidak berasal dari luar sedangkan 1.675 data atau setara 95,3\% komite audit secara keseluruhan berasal dari luar.

\section{Uji Outlier}

Data yang dikatakan outlier apabila data tersebut memiliki nilai z-score lebih dari 
-3 atau 3 jika sampel dalam observasi > 80 data (Ghozali, 2018). Berdasarkan hasil uji outlier terdapat sebanyak 208 data outlier dalam 1.965 data yang perlu dieliminasi dan tidak digunakan untuk uji data selanjutnya. Berikut jumlah data setelah dikurangi dengan data outlier tersisa sebanyak 1.757 sampel yang akan diambil untuk tahap pengujian selanjutnya.

\section{Uji Multikolinearitas}

Pengujian data pada uji multikolinearitas dengan tujuan untuk mengetahui terdapat atau tidak terdapatnya dari masing-masing variabel independen yang memiliki data yang sama. Apabila Variance Inflation Factor atau VIF > 10 atau tolerance value $<0,1$ maka dapat dinyatakan bahwa model regresi terdapat multikolinearitas (Ghozali, 2018). Berdasarkan hasil uji multikolinearitas, semua variabel penelitian telah memenuhi kriteria dimana nilai VIF nya $<10$ dan nilai tolerance $>0,1$, sehingga dapat dikatakan bahwa data tidak terjadi multikolinearitas yang artinya masing-masing variabel tidak memiliki data yang sama.

\section{Uji Hipotesis}

\section{Uji Hosmer and Lemeshow}

Pengujian data pada hosmer and lemeshow ini memiliki tujuan untuk mengetahui tingat kesesuaian model dengan data. Dikatakan signifikan apabila nilai > 0,05 maka model tersebut dapat diterima atau sesuai dan sebaliknya (Ghozali, 2018). Berdasarkan hasil uji hosmer and lemeshow, memperoleh hasil signifikan sebesar 0,933 artinya variabel kesulitan keuangan dapat memprediksi nilai observasi model atau model dikatakan sesuai.

\section{Uji Nagelkerke $\boldsymbol{R}^{2}$}

Pengujian data dalam uji nagelkerke $r^{2}$ dengan tujuan untuk mengetahui persentase kecocokan suatu model dengan melihat tingkat kemampuan variabel independen dalam menjelaskan variabel dependen (Ghozali, 2018). Berdasarkan hasil uji, memperoleh nilai nagelkerke $r^{2}$ sebesar $76,9 \%$ yang artinya variabel dependen dapat dijelaskan oleh variabel bebas sebesar 76,9\% dan sisanya $23,1 \%$ adalah variabel lain yang menjelaskan variabel dependen, namun tidak terdapat pada model penelitian ini.

\section{Uji Variables in the Equation (Uji Wald)}

Tabel 4. Hasil Uji Variables in the Equation (Uji Wald)

\begin{tabular}{|c|c|c|c|c|}
\hline Variabel & Koef. & Sig. & Kesimpulan & Hipotesis \\
\hline OD & $-0,051$ & 0,942 & $\begin{array}{c}\text { Tidak } \\
\text { Signifikan }\end{array}$ & $\begin{array}{c}\text { Tidak } \\
\text { Terbukti }\end{array}$ \\
\hline MO & 4,349 & 0,003 & Signifikan (+) & $\begin{array}{c}\text { Tidak } \\
\text { Terbukti }\end{array}$ \\
\hline $\mathrm{IO}$ & $-1,837$ & 0,001 & Signifikan (-) & Terbukti \\
\hline IC & 1,010 & 0,311 & $\begin{array}{c}\text { Tidak } \\
\text { Signifikan }\end{array}$ & $\begin{array}{c}\text { Tidak } \\
\text { Terbukti }\end{array}$ \\
\hline $\begin{array}{l}\text { Uk. Dewan } \\
\text { Komisaris }\end{array}$ & $-0,023$ & 0,750 & $\begin{array}{c}\text { Tidak } \\
\text { Signifikan }\end{array}$ & $\begin{array}{c}\text { Tidak } \\
\text { Terbukti }\end{array}$ \\
\hline $\begin{array}{c}\text { Uk. Dewan } \\
\text { Direksi }\end{array}$ & $-0,271$ & 0,000 & Signifikan (-) & Terbukti \\
\hline $\mathrm{ACC}$ & $-0,970$ & 0,076 & - & - \\
\hline EB & 0,685 & 0,189 & - & - \\
\hline Likuiditas & $-4,498$ & 0,000 & - & - \\
\hline Leverage & 8,688 & 0,000 & - & - \\
\hline Firm Size & $-0,343$ & 0,000 & - & - \\
\hline Constant & 10,245 & 0,001 & & \\
\hline
\end{tabular}

Sumber: Data sekunder diolah (2021)

Pengujian wald dilakukan dengan tujuan untuk mengetahui seberapa pengaruh variabel dependen dapat dipengaruhi oleh masing-masing dari variabel independen itu sendiri. Dikatakan signifikan apabila nilai < 0,05 maka variabel dependen dinyatakan terpengaruh oleh variabel independen (Ghozali, 2018). Pada Tabel 4, dapat diketahui bahwa variabel Outside Directors (OD) memiliki nilai signifikan 0,942 dengan 
nilai koefisien $-0,051$. Hal ini membuktikan bahwa variabel Outside Directors (OD) tidak berpengaruh terhadap kesulitan keuangan sehingga untuk $\mathrm{H} 1$ dinyatakan tidak terbukti.

Variabel Managerial Ownership (MO) memiliki nilai signifikan sebesar 0,003 dengan nilai koefisien 4,349 yang dimana secara signifikan Managerial Ownership (MO) berpengaruh terhadap kesulitan keuangan dengan arah positif. Namun, untuk H2 dinyatakan tidak terbukti. Variabel Institutional Ownership (IO) memiliki nilai signifikan sebesar 0,001 dengan nilai koefisien $-1,837$ yang berarti variabel Institutional Ownership (IO) berpengaruh signifikan negatif terhadap kesulitan keuangan sehingga untuk $\mathrm{H} 3$ dinyatakan terbukti.

Variabel Independent Commissioners (IC) memiliki nilai signifikan sebesar 0,311 dengan nilai koefisien 1,010 yang artinya variabel Independent Commissioners (IC) tidak berpengaruh terhadap kesulitan keuangan. Maka dari itu, untuk $\mathrm{H} 4$ dinyatakan tidak terbukti.

Variabel ukuran dewan komisaris memiliki nilai signifikan sebesar 0,750 dengan nilai koefisien $-0,023$ yang artinya tidak terdapat pengaruh antara variabel ukuran dewan komisaris dan kesulitan keuangan sehingga untuk H5 dinyatakan tidak terbukti. Variabel ukuran dewan direksi memiliki nilai signifikan sebesar 0,000 dengan nilai koefisien $-0,271$ yang artinya variabel ukuran dewan direksi berpengaruh signifikan negatif terhadap kesulitan keuangan, sehingga untuk H6 dinyatakan terbukti.

\section{Pembahasan \\ Pengaruh Outside Directors Terhadap Kesulitan Keuangan}

Berdasarkan hasil uji wald, variabel Outside Directors (OD) secara signifikan tidak berpengaruh terhadap kesulitan keuangan. Outside Directors (OD) adalah direktur independen atau non-eksekutif yang berperan dalam menentukan profitabilitas perusahaan melemah pada saat periode krisis (Kyriazopoulos, 2017). Semakin banyak perusahaan yang tidak memiliki Outside Directors (OD) akan menyebabkan manajemen bertindak secara leluasa dalam mengambil kebijakan yang dapat menguntungkan bagi mereka dan akan merugikan perusahaan (Widhiastuti et al., 2019). Dalam riset ini, rata-rata proporsi Outside Directors (OD) hanya sebesar 14,28\% yang artinya keberadaan Outside Directors (OD) dalam komposisi dewan direksi hanya sebesar $14,28 \%$ sehingga Outside Directors (OD) diasumsikan tidak memiliki keefektifan dalam perusahaan karena sangat minimnya keberadaan Outside Directors (OD) dalam perusahaan. Hasil penelitian tersebut searah dengan penelitian yang dikemukakan oleh Ahmad \& Adhariani (2017).

\section{Pengaruh Managerial Ownership Terhadap Kesulitan Keuangan}

Berdasarkan hasil uji wald, variabel Managerial Ownership (MO) berpengaruh signifikan positif terhadap kesulitan keuangan. Saham yang dimiliki oleh manajerial akan mempengaruhi sikap manajer dalam bertindak dan mengambil keputusan perusahaan. Managerial Ownership (MO) yang semakin tinggi maka saham yang dimiliki oleh perusahaan akan semakin banyak pula sehingga manajemen mampu bertindak abuse power yang akan 
mengakibatkan perusahaan mengalami kesulitan keuangan bahkan mengarah kepada kebangkrutan perusahaan (Ma'ruf \& Kresnamurti, 2021). Hasil ini sejalan dengan riset temuan Mulansari \& Setiyorini (2019) yang juga menjelaskan bahwa Managerial Ownership (MO) memiliki pengaruh signifikan positif terhadap kesulitan keuangan.

\section{Pengaruh Institutional Ownership Terhadap Kesulitan Keuangan}

Berdasarkan hasil uji wald, variabel Institutional Ownership (IO) secara signifikan berpengaruh negatif terhadap kesulitan keuangan. Institutional Ownership (IO) berfungsi untuk mengurangi masalah keagenan karena pada dasarnya pemegang saham institutional bertugas untuk membantu perusahaan dalam mengawasi manajemen supaya tidak menimbulkan hal yang merugikan pemegang saham. Semakin tinggi Institutional Ownership (IO) maka perusahaan akan semakin efisien dalam memanfaatkan asetnya sehingga kemungkinan terjadinya kesulitan keuangan dapat diminimalisir. Hal tersebut terjadi karena kepemilikan investor institusi akan semakin ketat dalam melakukan pengawasan terhadap manajemen ketika menyajikan laporan keuangan sehingga manajemen aktif dalam menjalankan kinerja dan melaporkan nilai laba bersih dalam laporan keuangan (Setyaningsih \& Gunarsih, 2018). Semakin besar persentase Institutional Ownership (IO), maka kemungkinan resiko perusahaan mengalami kesulitan keuangan lebih rendah. Pernyataan tersebut didukung oleh Setyaningsih \& Gunarsih (2018) dan juga sejalan dengan penelitian lainnya yaitu, Nurhujaima et al. (2021), Maghfiroh \& Isbanah (2020), dan Anggraini (2014) yang menjelaskan adanya pengaruh signifikan negatif antara Institutional Ownership (IO) dan kesulitan keuangan.

\section{Pengaruh Independent Commissioners Terhadap Kesulitan Keuangan}

Berdasarkan hasil uji wald, variabel Independent Commissioners (IC) tidak berpengaruh terhadap kesulitan keuangan. Independent Commissioners (IC) merupakan bagian dari dewan komisaris yang bertugas untuk bertindak sebagai pengawas manajer dalam penerapan sistem tata kelola perusahaan. Independent Commissioners (IC) dalam struktur dewan komisaris dianggap memiliki kinerja dalam meningkatkan efektivitas dewan komisaris (Widhiadnyana \& Ratnadi, 2019). Seorang Independent Commissioners (IC) memerlukan sikap yang independen dalam melaksanakan tugasnya, namun terkadang seorang Independent Commissioners (IC) tidak memiliki sikap pengawasan yang kuat terhadap kinerja manajemen sehingga tidak memiliki pengaruh terhadap kesulitan keuangan (Putri, 2018). Hasil riset ini sejalan dengan riset yang dikemukakan oleh Yanti et al. (2018), Radifan \& Yuyetta (2015), dan Cinantya \& Merkusiwati (2015) yang menyatakan tidak terdapatnya hubungan signifikan antara Independent Commissioners (IC) dan kesulitan keuangan.

\section{Pengaruh Ukuran Dewan Komisaris Terhadap Kesulitan Keuangan}

Berdasarkan hasil uji wald, variabel ukuran dewan komisaris tidak berpengaruh terhadap kesulitan keuangan. Dewan komisaris merupakan bagian dari dewan dalam suatu tata kelola perusahaan yang berfungsi sebagai pengawas upaya meminimalisir agency problem agar timbul keselarasan kepentingan antara pemilik dan pihak manajer (Hanifah \& Purwanto, 2013). 
Namun, hal tersebut terkadang tidak dapat disesuaikan dengan harapan yang dikehendaki oleh perusahaan karena dewan komisaris juga akan mengalami yang namanya human error dimana terdapat kelalaian dari kinerjanya. Tinggi atau rendahnya suatu ukuran dewan komisaris tidak memiliki pengaruh terhadap kesulitan keuangan. Hal tersebut didukung oleh peneliti Harahap (2017) dan Muhammad et al. (2018) yang menunjukkan bahwa ukuran dewan komisaris tidak memiliki pengaruh terhadap kesulitan keuangan.

\section{Pengaruh Ukuran Dewan Direksi Terhadap Kesulitan Keuangan}

Berdasarkan hasil uji wald, variabel ukuran dewan direksi memiliki signifikan negatif terhadap kesulitan keuangan. Dalam teori agency menjelaskan dewan direksi sebagai suatu mekanisme dalam tata kelola perusahaan yang memiliki fungsi untuk mengurangi agency problem dalam jangka panjang yang dapat menimbulkan indikator kebangkrutan atau menciptakan nilai tambah demi kepentingan semua pihak agar tidak terjadi konflik antara pihak agen dan prinsipal (Hanifah \& Purwanto, 2013). Semakin tinggi jumlah dewan direksi menandakan kemungkinan terjadinya financial distress pada perusahaan akan semakin kecil pula. Sehingga, dewan direksi memiliki peranan penting dalam tata kelola perusahaan, dimana keberadaannya menentukan kinerja perusahaan (Hanifah \& Purwanto, 2013). Hasil riset ini sejalan dengan riset temuan Sumani (2019) yang menjelaskan bahwa ukuran dewan direksi memiliki pengaruh negatif terhadap kesulitan keuangan.

Copyright (C) 2021, FINANCIAL: Jurnal Akuntansi

\section{SIMPULAN DAN SARAN \\ Kesimpulan}

Berdasarkan hasil pengujian dan pembahasan diatas, dapat disimpulkan bahwa Institutional Ownership (IO) dan ukuran dewan direksi memiliki pengaruh signifikan negatif pada kesulitan keuangan yang artinya semakin tinggi Institutional Ownership (IO) maka perusahaan akan semakin efisien dalam memanfaatkan asetnya sehingga kemungkinan terjadinya kesulitan keuangan dapat diminimalisir dan ukuran dewan direksi yang semakin tinggi akan mengurangi terjadinya agency problem yang dapat menimbulkan indikator kebangkrutan karena keberadaan dewan direksi dapat menentukan kualitas kinerja perusahaan sehingga kesulitan keuangan akan sulit terjadi. Sedangkan, Managerial Ownership (MO) memiliki pengaruh signifikan positif terhadap kesulitan keuangan dikarenakan semakin tinggi saham yang dimiliki oleh manajerial maka manajemen mampu bertindak abuse power yang dapat mengakibatkan perusahaan mengalami kesulitan keuangan. Sementara itu, Outside Directors (OD), Independent Commissioners (IC), dan ukuran dewan komisaris tidak memiliki pengaruh terhadap kesulitan keuangan.

\section{Saran}

Penelitian ini memiliki keterbatasan yang menyebabkan peneliti tidak dapat memaparkan secara leluasa yaitu variabel external blockholder dan audit committee composition dimana data penelitiannya masih sangat minim dan sedikitnya peneliti yang meneliti terkait variabel dan pengukuran yang sesuai dengan variabel tersebut sehingga menghambat dalam proses pengembangan studi dalam penelitian ini. Selanjutnya, terdapat perusahaan yang tidak 
publikasikan laporan tahunan dan keuangan secara lengkap selama lima tahun, sehingga tidak dapat diambil sebagai sampel penelitian. Rekomendasi untuk peneliti selanjutnya, dapat menambahkan variabel profitabilitas untuk mengukur seberapa efisiensi dan efektivitas perusahaan dengan upaya mengetahui tingkat kemampuan perusahaan dalam menghasilkan laba dengan menggunakan asetnya.

\section{DAFTAR PUSTAKA}

Ahmad, H. M., \& Adhariani, D. (2017). Corporate governance determinants for the mitigation of the likelihood of financial distress. Advances in Economics, Business and Management Research, 36, 1-11. https://doi.org/https://doi.org/10.2991/ic bmr-17.2017.1

Anggraini, D. (2014). Financial distress model prediction for indonesian companies. International Journal of Management and Administrative Sciences (IJMAS), 3(04), 74-84.

Ayuningtyas, D. (2019). Kena suspensi (lagi), bagaimana nasib bakrie telecom? CNBC Indonesia. https://www.cnbcindonesia.com/market/ 20190527153633-17-75306/kenasuspensi--lagi--bagaimana-nasib-bakrietelecom

Baklouti, N., Gautier, F., \& Affes, H. (2016). Corporate governance and financial distress of european commercial banks. Journal of Business Studies Quarterly, 7(3), 75-96.

Cinantya, I. G. A. A. P., \& Merkusiwati, N. K. L. A. (2015). Pengaruh corporate governance, financial indicators, dan ukuran perusahaan pada financial distress. Jurnal Akuntansi Universitas Udayana, 10(3), 897-915.

Elloumi, F., \& Gueyié, J. P. (2001). Financial distress and corporate governance: an empirical analysis. The International Journal of Business in Society, 1(1), 15-
23.

Fashhan, M. R., \& Fitriana, V. E. (2018). The influence of corporate governance and intellectual capital towards financial distress. Journal of Applied Accounting and Finance, 2(2), 163-179.

Ghozali, I. (2018). Aplikasi analisis multivariate dengan program IBM SPSS 25 (I. Ghozali (ed.); Sembilan). Badan Penerbit Universitas Diponegoro.

Hanani, R. T., \& Dharmastuti, C. F. (2015). How do corporate governance mechanisms affect a firm's potential for bankruptcy? Risk Governance and Control: Financial Markets and Institutions, 5(1), 61-71.

Handayani, Y. D., Iskandar, D., \& Yuvisaibrani, E. (2019). Corporate governance and intellectual capital on financial distress. Global Journal of Management and Business Research: $C$ Finance, 19(5), 63-71.

Hanifah, O. E., \& Purwanto, A. (2013). Pengaruh struktur corporate governance and financial indicators terhadap kondisi financial distress. Diponegoro Journal of Accounting, 2(2), 1-15.

Harahap, L. W. (2017). Pengaruh mekanisme corporate governance dan firm size terhadap kondisi financial distress pada perusahaan property and real estate yang terdaftar di bei tahun 2010 - 2014. Jurnal Riset Akuntansi Dan Bisnis, 17(2).

Heniwati, E., \& Essen, E. (2020). Which retail firm characteristics impact on financial distress? Jurnal Akuntansi Dan Keuangan, 22(1), 40-46. https://doi.org/10.9744/jak.22.1.40-46

Ibrahim, R. (2019). Corporate governance effect on financial distress: evidence from indonesian public listed companies. Journal of Economics, Business, and Accountancy Ventura, 21(3), 415-422. https://doi.org/10.14414/jebav.v21i3.16 26

Islami, I. N., \& Rio, W. (2018). Financial ratio analysis to predict financial 
distress on property and real estate company listed in indonesia stock exchange. Journal of Applied Accounting and Finance, 2(2), 125-137.

Jamal, A. H., \& Shah, S. Z. A. (2017). The impact of corporate governance on the financial distress: evidence from pakistani listed companies. Jinnah Business Review, 5(2), 49-53.

Jensen, M. C., \& Meckling, W. H. (1976). Theory of the firm: managerial behavior, agency costs and ownership structure. Journal of Financial Economics, 3(4), 305-360.

John, A. T., \& Ogechukwu, O. L. (2018). Corporate governance and financial distress in the banking industry: nigerian experience. Journal of Economics and Behavioral Studies, 10(1), 182-193. https://doi.org/10.22610/jebs.v10i1(j).21 01

Khafid, M., Tusyanah, T., \& Suryanto, T. (2019). Analyzing the determinants of financial distress in indonesian mining companies. International Journal of Economics and Business Administration, 7(4), 353-368. https://doi.org/10.35808/ijeba/349

Khalid, M., Abbas, Q., Malik, F., \& Ali, S. (2020). Impact of audit committee attributes on financial distress: evidence from pakistan. International Journal of Financial Engineering, 7(1), 1-19. https://doi.org/10.1142/s242478632050 $005 \mathrm{x}$

Khaliq, A., Altarturi, B. H. M., Thaker, H. M. T., Harun, M. Y., \& Nahar, N. (2014). Identifying financial distress firms: a case study of malaysia' $s$ government linked companies (GLC). International Journal of Economic, Finance and Management, 3(3), 141150.

Khurshid, M. K., Sabir, H. M., Tahir, S. H., \& Abrar, M. (2019). Impact of ownership structure and board composition on financial distress of pakistan stock exchange listed manufacturing firms. International
Transaction Journal of Engineering, Management, \& Applied Sciences \& Technologies, 11(2), 1-14. https://doi.org/10.14456/ITJEMAST.20 20.26

Kyriazopoulos, G. (2017). Corporate governance and firm performance in periods of financial distress. Corporate Ownership and Control, 14(3), 209222.

https://doi.org/10.22495/cocv14i3c1art7

Ma'ruf, M. F., \& Kresnamurti, R. K. (2021). Pengaruh good corporate governance dan ukuran perusahaan terhadap financial distress pada perusahaan manufaktur sektor aneka industri yang terdaftar di bei. Jurnal Ilmiah Akuntansi Dan Bisnis, 3(1), 1-13.

Maghfiroh, R. D., \& Isbanah, Y. (2020). Pengaruh audit committee, ownership structure, dan chief executive officer terhadap financial distress pada perusahaan sektor perdagangan, jasa, dan investasi yang terdaftar di bursa efek indonesia pada tahun 2015-2018. Jurnal Ilmu Manajemen, 8(3), 10991115 .

Manzaneque, M., Priego, A. M., \& Merino, E. (2016). Corporate governance effect on financial distress likelihood: evidence from spain. Revista de Contabilidad-Spanish Accounting Review, 19(1), 111-121. https://doi.org/10.1016/j.rcsar.2015.04.0 01

Mesak, D., \& Made, S. I. (2019). Financial ratio analysis in predicting financial conditions distress in indonesia stock exchange. Russian Journal of Agricultural and Socio-Economic Sciences, 86(2), 155-165. https://doi.org/10.18551/rjoas.201902.18

Miglani, S., Ahmed, K., \& Henry, D. (2015). Voluntary corporate governance structure and financial distress: evidence from australia. Journal of Contemporary Accounting and Economics, 11(1), 1830. 
https://doi.org/10.1016/j.jcae.2014.12.0 05

Muhammad, S., Sadalia, I., \& Fachrudin, K. A. (2018). An analysis on the influence of fundamental factors, intellectual capital and corporate governance on bankruptcy prediction using springate (s- score) method in the mining companies listed on the indonesian stock exchange. International Journal of Research and Review, 5(11), 85-97.

Mulansari, R., \& Setiyorini, W. (2019). Pengaruh good corporate governance dan financial indicators terhadap financial distress pada perusahaan property dan real estate. Jurnal Akuntansi Dan Perpajakan, 5(2), 115126.

Murhadi, W. R., Tanugara, F., \& Sutejo, B. S. (2018). The influence of good corporate governance on financial distress. Advances in Social Science, Education and Humanities Research (ASSEHR), 186, 76-79. https://doi.org/10.2991/insyma18.2018 .19

Murtadha, M. A., Arfan, M., \& Saputra, M. (2018). Factors influencing financial distress and its impact on company values of the sub-sectors firms in Indonesian. Journal of Accounting Research, Organization and Economics, 1(2), 191-204 https://doi.org/10.24815/jaroe.v1i2.1188 3

Nurhujaima, Muda, I., \& Tarmizi, H. (2021). The effect of corporate governance mechanism, leverage, and profitability on financial distress with liquidity as moderating variables in manufacture companies listed on indonesia stock exchange (Idx). International Journal Public Budgeting, Accounting and Finance, 4(1), 2655-6693.

Ombaba, K. M. B., \& Kosgei, D. (2017). Board composition and financial distress of listed firms in kenya. an empirical analysis. Journal of Finance and Investment Analysis, 6(4), 75-93.
Pramudena, S. M. (2017). The impact of good corporate governance on financial distress in the consumer good sector. Journal of Finance and Banking Review, 2(4), 46-55.

Putri, E. L. (2018). Prediksi financial distress dengan analisis risk, good corporate governance, earnings, capital, dan size pada bank umum swasta nasional devisa. Management and Business Review, 2(2), 93-105. https://doi.org/10.21067/mbr.v2i2.3226

Putri, N. W. K. A., \& Merkusiwati, N. K. L. A. (2014). Pengaruh mekanisme corporate governance, likuiditas, leverage, dan ukuran perusahaan pada financial distress. Jurnal Akuntansi Universitas Udayana, 7(1), 93-106.

Radifan, R., \& Yuyetta, E. N. A. (2015). Analisis pengaruh mekanisme good corporate governance terhadap kemungkinan financial distress. Diponegoro Journal of Accounting, 4(3), 1-11.

Revitasari, F. T., Nurdin, \& Azib. (2017). Pengaruh karakteristik komite audit terhadap financial distress. Jurnal Manajemen Universitas Islam Bandung, 3, 289-293.

Rianti, I. P., \& Yadiati, W. (2018). The influence of firm size on financial distress: A research on agricultural companies listed in indonesia stock exchange. In International Business Management (Vol. 12, Issue 4, pp. 365369).

Setyaningsih, T., \& Gunarsih, T. (2018). The effect of financial ratio and corporate governance mechanisms on the financial distress in the indonesia stock exchange. Journal of Applied Economics in Developing Countries, 3(2), 59-66.

Sidik, S. (2020). 50 lebih emiten cuma kuat sampai juni, ini sektor tersengsara. CNBC Indonesia. https://www.cnbcindonesia.com/market/ 20200513100913-17-158086/50-lebihemiten-cuma-kuat-sampai-juni-inisektor-tersengsara 
Sumani, S. (2019). The structure of good corporate governance and financial indicators as predictor of financial distress in mining sector company in indonesia. Research in Business and Management, $\quad 6(1), \quad 1$. https://doi.org/10.5296/rbm.v6i1.13440

Suprayitno, D. (2017). Emiten baik harus memerangi korupsi. Kontan.Co.Id. https://investasi.kontan.co.id/news/emite n-baik-harus-memerangi-korupsi

Udin, S., Khan, M. Y., Javeed, A., \& Pham, H. (2020). Board structure and likelihood of financial distress: an emerging asian market perspective. Journal of Asian Finance, Economics and Business, 7(11), 241-250. https://doi.org/10.13106/jafeb.2020.vol7 .no11.241

Widhiadnyana, I. K., \& Ratnadi, N. M. D. (2019). The impact of managerial ownership, institutional ownership, proportion of independent commissioner, and intellectual capital on financial distress. Journal of Economics, Business, and Accountancy Ventura, 21(3), 351-360. https://doi.org/10.14414/jebav.v21i3.12 33

Widhiastuti, R., Nurkhin, A., \& Susilowati, N. (2019). The role of financial performance in mediating the effect of good corporate governance on financial distress. Jurnal Economia, 15(1), 3447.

Widyasari, P. A., \& Kurniawan, E. C. (2020). Pengaruh pelaporan keuangan melalui internet dan tata the effect of internet financial reporting and corporate. Jurnal Akuntansi, 10(2), 165-182. https://doi.org/https://doi.org/10.33369/j .akuntansi.9.3.165-182

Yanti, I., Asnawi, D. M., \& Simanjuntak, A. M. . (2018). Mekanisme internal dan eksternal corporate governance dalam memitigasi financial distress. Jurnal Akuntansi Dan Keuangan Daerah, 13(1), 1-15.

Yudha, A. (2014). Analisis pengaruh

Copyright (C) 2021, FINANCIAL: Jurnal Akuntansi penerapan mekanisme corporate governance terhadap kemungkinan perusahaan (studi empiris perusahaan manufaktur yang terdaftar di bursa efek indonesia tahun 2010-2012). Diponegoro Journal of Accounting, 3(4), 1.

Zelie, E. M. (2019). Determinants of financial distress in case of insurance companies in ethiopia. Research Journal of Finance and Accounting, 10(15), 27-32. https://doi.org/10.7176/RJFA/10-15-05 